\title{
ANALYSIS OF SMOKING HABITS AND MONOXIDE CARBON CONTENTS IN HOME WITH CARBOXIHEMOGLOBINE (COHb) IN ACTIVE SMOKING IN III ENVIRONMENT, KEMARAYA, KENDARI CITY
}

\author{
Sari Arie Lestari B ${ }^{1}$, Titi Saparina L. $^{2}$, Leniarti Ali ${ }^{3}$ \\ ${ }^{1,2,3}$ Universitas Mandala Waluya, in Kendari Southeast Sulawesi Province, \\ Indonesia
}

Corresponding Author: Sari Arie Lestari B

Email : sariariel.83@gmail.com

\begin{abstract}
Background: around 10,000,000 people is estimated to be death per year by 2020 because of smoking. Smokers emit smoke around 20,000 ppm of CO, when it is inhaled. It will become diluted with a concentration of around 400 until 5,000 ppm. This situation is dangerous because it will increase the $\mathrm{COHb}$ concentration in the human blood by up to $6.9 \%$. It can prone to heart attacks. The purpose of this research is to analyze smoking habits and $\mathrm{CO}$ levels in the house with carboxyhemoglobin $(\mathrm{COHb})$ levels in active smokers in 3 Districts of Kemaraya in Kendari City.

Methods: The research was conducted using the Analytical Descriptive method. Data were collected by interview using a structured questionnaire and laboratory analysis. While the approach used is a crosssectional study. The population in this study was 81 and the number of samples was 45 .

Results: The The results obtained were that there was no relationship between $\mathrm{CO}$ and $\mathrm{COHb}$ levels ( $\mathrm{p}$ value $=0.623>0.05)$; there was a weak relationship between smoking and $\mathrm{COHb}$ levels ( $\mathrm{p}$ value $=$ $0.029<0.05$ ); and there is a low relationship between the number of cigarettes and COHb levels ( $\mathrm{p}$ value $=0.0298<0.05$ )

Conclusion: It can be concluded that there is an insignificant relationship between smoking duration, types of cigarettes smoked, number of cigarettes smoked and levels of carbon monoxide in the house and levels of carboxyhemoglobin $(\mathrm{COHb})$ in active smokers in environment III District of Kemaraya Kendari City.
\end{abstract}

Keywords: Smoking, Carbon monoxide, Carboxy hemoglobin, Active 


\section{INTRODUCTION}

Smoking is a health problem in society and is a big threat to health in the world. Smoking has implications for various major risk factors for disease, such as chronic obstructive pulmonary disease, emphysema and various heart diseases. The number of deaths due to smoking if smoking continues, is estimated to be around $10,000,000$ people per year by 2020 , and $70 \%$ of them will occur in developing countries in various parts of the world[1].

Carbon Monoxide is also produced from cigarette smoke which can cause indoor air pollution. Indoor air pollution is very dangerous because the source is in direct proximity to humans. Until now, more than 4,000 chemicals have been known to be contained in cigarette smoke, including $\mathrm{CO}[2]$. The concentration of $\mathrm{CO}$ in the room increases when there is a clog. Smokers emit smoke containing a concentration of 20,000 ppm of $\mathrm{CO}$, when smoked it will become dilute with a concentration of around 400 $5,000 \mathrm{ppm}$. This situation is dangerous because it will increase the $\mathrm{COHb}$ concentration in the blood by up to $6.9 \%$, making it prone to heart attacks [3].

Carbon Monoxide (CO) has a strong tendency to bind to hemoglobin in red blood cells, this bond is 210-300 times stronger than that of hemoglobin with oxygen (oxyhemoglobin). Supposedly, this hemoglobin binds to oxygen which is essential for respiration of the body's cells, but because $\mathrm{CO}$ gas is stronger than oxygen, this CO gas takes its place. So, hemoglobin coupled with $\mathrm{CO}$ gas. The level of $\mathrm{CO}$ gas in the blood of nonsmokers is less than 1 percent, while in the blood of smokers it reaches 4 - 15 percent. If the situation continues, polycythemia will occur which affects central nerve function.

Based on the 2013 RISKESDAS data according to smoking habits in Indonesia, Southeast Sulawesi Province has the number of smokers in Indonesia with a total percentage of $19.8 \%$. Kendari City is the capital city of Southeast Sulawesi Province. Based on Riskesdas data, the prevalence of smoking in the house was $89.6 \%$ and based on the initial survey in Environment III of Kemaraya Village Kendari City, information was obtained that the smoking habit in the house had become a tradition by the head of the family. In daily activities, the habit of the head of the household who smokes in the house, where the cigarette smoked will release carbon monoxide which will worsen indoor air quality and will result in carboxyhemoglobin in the human body, therefore some parts of the body do not get enough oxygen [4].

The purpose of this study is that the researcher wants to analyze smoking habits (number of cigarettes smoked, length of smoking, type of cigarette) with carboxyhemoglobin in active smokers in the Kemaraya Family Environment III District of Kemaraya Kendari City. As well as analyzing $\mathrm{CO}$ levels in the house with carboxyhemoglobin in active smokers in Environment III District of Kemaraya Kendari City.

\section{METHOD}

This type of research is a descriptive study with a cross sectional study approach [5]. Data on smoking habits were collected by interview using a structured questionnaire and in-depth analysis of carboxyhemoglobin $(\mathrm{COHb})$ levels by laboratory tests and indoor carbon monoxide levels.

The population in this study were all household heads who resided in Environment III District of Kemaraya Kendari City who became active smokers, totaling 81 people. The number of samples used the Yamane formula quoted by Surakhmad (1994) using a precision of $10 \%$ in order to obtain a sample of 45 respondents. Sampling was done by purposive sampling.

The selected sample was then interviewed using a questionnaire to obtain data on smoking duration, number of 
cigarettes and type of cigarette smoked. Then blood samples were taken to check the $\mathrm{COHb}$ levels in the blood using a spectrophotometer. The sample is taken to the Diagnostic laboratory for analysis. Meanwhile, the CO level in the house was measured using an NDIR Analyzer. Meanwhile, secondary data were obtained through observation of the research location, as well as articles related to this study.

Then the data was processed using a computer with SPSS version 16.0 software. Univariate analysis was performed to describe all variables, both independent and dependent variables. After determining the characteristics of each variable, the analysis of the relationship between the two variables can be continued. Before the independent and dependent variables are analyzed, the Kolmogorov Smirnov test is first performed to test the data normality, if the data is normally distributed then the Pearson Product Moment correlation test is used. If the data is not normally distributed, the Rank Spearman correlation test is used. Hypothesis testing / drawing conclusions on each statistical analysis results using a 95\% confidence level $(\alpha=0.05)$ [5].

In the research implementation process, the head of the study identified the health problems to be raised. Then the chairperson and members carry out an indepth study of health problems. The results of identification and assessment of health problems are then discussed together, followed by looking for literature references and compiling research proposals. During the implementation of the research, the chairperson and members jointly collected data and carried out a calibration test for measuring $\mathrm{CO}$ and $\mathrm{COHb}$ levels and carried out the validity and reliability of the specified instrument to be assisted by the technician. Processing of data collection results, carried out jointly between the chairman and members. The implementation of analysis and presentation is the responsibility of the chairman, while members play a role in the collection, correspondence and preparation of reports.

This data collection was carried out during the Covid 19 pandemic, so that in its implementation researchers still pay attention to the Covid 19 protocol. Because there were 45 respondents, so blood sampling was carried out gradually.

Meanwhile, the research ethics carried out by researchers were informed consent, anonymity, and confidentiality.

\section{RESULT}

\section{Characteristics of respondents}

Age

Table 1 Characteristics of Respondents

by Age
\begin{tabular}{|c|c|c|}
\hline Age & $\mathrm{n}$ & $\%$ \\
\hline $\begin{array}{c}30- \\
40\end{array}$ & 20 & 44.44 \\
$41-$ & 17 & 37.78 \\
50 & & \\
\hline $\begin{array}{c}51- \\
60\end{array}$ & 8 & 17.78 \\
\hline Total & 45 & 100 \\
\hline
\end{tabular}

From table 1 it can be concluded that there were 20 respondents aged 30-40 years $(44.44 \%)$, then respondents aged $41-50$ years were 17 respondents $(37.78 \%)$, while respondents aged $51-60 \%$ were 8 respondents $(17.78 \%)$.

\section{Gender}

Table 2 Characteristics of Respondents

\begin{tabular}{|c|c|c|} 
by Gender \\
\begin{tabular}{|c|c|c|}
\hline Gender & $\mathrm{n}$ & $\%$ \\
\hline Men & 45 & 100 \\
\hline Women & 0 & 0 \\
\hline Total & 45 & 100 \\
\hline
\end{tabular}
\end{tabular}

From table 2 it can be concluded that the respondents in this study were all male. 
Univariate Analysis

\section{Number of Cigarettes}

Table 3 Distribution of Respondents Based on Number of Cigarettes

\begin{tabular}{|c|c|c|}
\hline Variable & $\mathrm{n}$ & $\%$ \\
\hline $\begin{array}{c}\text { Number of } \\
\text { cigarrets }\end{array}$ & & \\
\hline$>10$ Bars / Day & 27 & 60 \\
\hline$\leq 10$ Bars / Day & 18 & 40 \\
\hline Total & 45 & 100 \\
\hline
\end{tabular}

From table 3 it can be concluded that respondents who smoked>10 bars / day were 27 respondents $(60 \%)$, and respondents who smoked < 10 bars / day were 18 respondents $(40 \%)$.

\section{Durating Smoking}

Table 4 Distribution of Respondents by Duration of Smoking

\begin{tabular}{|c|c|c|}
\hline Variable & $\mathrm{n}$ & $\%$ \\
\hline $\begin{array}{l}\text { Durating } \\
\text { Smoking }\end{array}$ & & \\
\hline$>2$ Years & 33 & 73.3 \\
\hline$\leq 2$ Years & 12 & 26.7 \\
\hline Total & 45 & 100 \\
\hline
\end{tabular}

From table 4 it can be concluded that respondents with duration of smoking> years were more than 33 respondents $(73.3 \%)$, and respondents with smoking duration $<2$ years were 12 respondents $(26.7 \%)$

\section{Types of Cigarettes}

Table 5 Distribution of Respondents by Type of Cigarettes

\begin{tabular}{|c|c|c|}
\hline Variabel & $\mathrm{n}$ & $\%$ \\
\hline $\begin{array}{c}\text { Types of } \\
\text { Cigarettes }\end{array}$ & & \\
\hline Filtered & 33 & 71.1 \\
\hline Not filtered & 12 & 26.7 \\
\hline Total & 45 & 100 \\
\hline
\end{tabular}

From table 5 it can be concluded that respondents who smoke with filtered cigarettes are 33 respondents $(73.3 \%)$, and
12 respondents $(26.7 \%)$ who smoke nonfiltered cigarettes.

\section{CO levels in the room}

Table 6 Distribution of Respondents Based on Indoor CO Levels

\begin{tabular}{|c|c|c|}
\hline \multicolumn{1}{|c|}{$\begin{array}{c}\text { Variable } \\
\text { Indoor CO } \\
\text { levels }\end{array}$} & $\mathrm{n}$ & $\%$ \\
\hline $\begin{array}{l}>\quad 30.000 \\
\mu \mathrm{g} / \mathrm{Nm}^{3}\end{array}$ & 12 & 26.7 \\
\hline $\begin{array}{l}\leq 30.000 \\
\mu \mathrm{g} / \mathrm{Nm}^{3}\end{array}$ & 33 & 73.3 \\
\hline Total & 45 & 100 \\
\hline
\end{tabular}

From table 6 it can be concluded that respondents with indoor $\mathrm{CO}$ levels $<30,000$ $\mu \mathrm{g} / \mathrm{Nm} 3$ were more than 33 respondents $(73.3 \%)$, and respondents with indoor $\mathrm{CO}$ levels> 30,000 $\mu \mathrm{g} / \mathrm{Nm} 3$ were 12 respondents $(26.7 \%)$.

\section{COHb levels}

Table 7 Distribution of Respondents Based on $\mathrm{COHb}$ Levels

\begin{tabular}{|l|c|c|}
\hline \multicolumn{1}{|c|}{ Variable } & $\mathrm{n}$ & $\%$ \\
\hline COHb Levels & & 20 \\
\hline $\begin{array}{l}\text { COHb } \\
\text { levels }>10 \%\end{array}$ & 9 & 20 \\
\hline $\begin{array}{l}\text { Kadar levels }< \\
10 \%\end{array}$ & 36 & 80 \\
\hline \multicolumn{1}{|c|}{ Total } & 45 & 100 \\
\hline
\end{tabular}

From table 7 it can be concluded that respondents with $\mathrm{COHb}$ levels $<10 \%$ were more than 36 respondents $(80 \%)$, and respondents with $\mathrm{COHb}$ levels> $10 \%$ were 9 respondents $(20 \%)$.

\section{Bivariate Analysis}

After doing the normality test using the Kolmogorof Smirnof test, it was found that the data were normally distributed. So that the statistical test used is the Pearson Product Moment correlation test. So that the analysis of smoking habits and levels of carbon monoxide in the house with carboxyhemoglobin $(\mathrm{COHb})$ in active smokers in Environment III District of 
Kemaraya Kendari City can be seen in table 8 below;

\section{Table 8 Bivariate Analysis of Monoxide Levels,}

Duration of smoking, types of cigarettes, and number of cigarettes with $\mathrm{COHb}$ levels in active smokers

\begin{tabular}{|l|c|c|}
\hline \multirow{2}{*}{ Variable } & \multicolumn{2}{c|}{ C0 HB levels } \\
\cline { 2 - 3 } & sig & $\alpha$ \\
\hline Monoxide levels & 0.623 & 0,05 \\
\hline Durating of Smoking & 0.029 & 0,05 \\
\hline $\begin{array}{l}\text { Number of cigarettes } \\
\text { smoked }\end{array}$ & 0.298 & 0,05 \\
\hline $\begin{array}{l}\text { Type of cigarette } \\
\text { smoked }\end{array}$ & 0.000 & 0,05 \\
\hline
\end{tabular}

Primary Data Sources for 2020

From table 8 it can be seen that the value of $\alpha$ is 0.05 , so it can be concluded that there is an insignificant relationship between monoxide levels, length of smoking, the number of cigarettes smoked and the type of cigarette smoked with carboxyhemoglobin $(\mathrm{COHb})$ levels in active smokers in Environment III District of Kemaraya Kendari City.

\section{DISSCUSION \\ Durating of Smoking}

Of the total 45 samples we studied, 33 samples had smoked for more than 2 years or as much as $73.3 \%$, while 12 samples or $26.7 \%$ of the other samples stated that they had smoked for less than 2 years. As it is known that people who smoke for 10 years get a decrease in HDL cholesterol, which means that it increases the factor of atherosclerosis or calcification of blood vessels. Although the data above shows that there are still samples who started smoking less than two years, in fact the smokers group has become a group at risk of developing degenerative diseases. Because just one cigarette contains approximately 4000 types of chemicals with $40 \%$ toxic content.

Cigarettes also contain carbon monoxide (CO). One cigarette that is burned contains $3-6 \%$ carbon monoxide and the blood level reaches 5\%. In non-smokers, the level is $1 \%$. Smokers with carbon monoxide levels of $5 \%$ and above had three times more attacks than nonsmokers. The combination of carbon monoxide with nicotine will make it easier for smokers to suffer from narrowing and closing of blood vessels with its consequences [6].

According to health data published by the British Heart Foundation, smoking can make the chemicals contained in it stick to artery walls. This condition clogs the arteries that carry blood to the heart and can cause a heart attack. This fact shows that smoking can increase a person's risk of heart disease by four times.

\section{Number of cigarettes smoked}

Regarding the number of cigarettes smoked, our results show that 27 people $(60 \%)$ in the sample smoked with more than 10 cigarettes smoked. Meanwhile, 18 people (40\%) smoked less than 10 cigarettes per day. Based on the number of cigarettes smoked, this can basically be a reference for us to divide the types of smokers based on the number of cigarettes smoked. From this study, it can be seen that the samples in this study were categorized as light smokers, some were moderate.

Light smokers are those who smoke less than 10 cigarettes per day. In contrast, moderate and heavy smokers are those who smoke more than 10 to 20 cigarettes per day. Based on the data above, moderate to heavy smokers were seen as dominant, namely 27 people. The number of cigarettes even though it is less than 10 cigarettes per day actually still affects one's health. If a cigarette is consumed in ten cigarette smoke suction, within a year for a smoker a total of 10 cigarettes (one pack) per day will experience 35,000 cigarette smoke suction[7]. Chemical substances contained in cigarettes will experience a buildup, until one day the dose of the poison will reach a toxic point and will cause various symptoms of disease [8]. 
Every time someone smokes, nicotine will be absorbed by the blood and then flow to the brain. Generally, smokers absorb 1$1.5 \mathrm{mg}$ of nicotine from one cigarette. Once in the brain, nicotine will increase the release of dopamine, a chemical that helps improve mood and lead to feelings of satisfaction.

Nicotine can have a temporary pleasure effect on the brain, which makes a person dependent on this substance. People who are addicted will usually show several physical and mental symptoms such as feeling anxious, irritable, diarrhea, difficulty concentrating, constipation to insomnia when they don't get nicotine intake.

So that for the treatment or management of active smokers who have been addicted to cigarettes, starting from counseling, giving drugs to behavioral therapy.

\section{Types of Cigarettes Smoked}

As for the types of cigarettes smoked, based on the table above, it shows that 33 samples or $73.3 \%$ of the samples smoked filtered types of cigarettes, while 12 samples or $26.7 \%$ of the samples used unfiltered cigarettes. This shows that the respondents who use filtered cigarettes are more than the respondents who use unfiltered cigarettes. Filter cigarettes, also known as white cigarettes, are cigarettes without clove mixtures such as those found in kretek or unfiltered cigarettes. The difference between the two cigarettes is based on the blend of their content and also the presence of a filter at the end of the cigarette [1]. In filter cigarettes the tar and nicotine content is lower when compared to kretek or unfiltered cigarettes. Filters are generally made from cellulose acetate, which is usually obtained from processed wood. This material is used because of its ability to filter tar and nicotine from cigarettes, so it is believed that the tar and nicotine inhaled is lower when compared to unfiltered cigarettes, so people tend to increase the number of cigarette consumption per day [9]. However, filter cigarettes can actually have a negative impact on the body because the fibers in the filter made of cellulose acetate can be inhaled along with cigarette smoke[10].

However, both filtered and nonfiltered, smokers are still susceptible to diseases caused by the nicotine content in cigarettes. Kretek (non-filtered) cigarettes contain $60-70 \%$ tobacco, the remaining 30$40 \%$ cloves and other ingredients, cloves contain eugenol which is considered to have the potential to cause cancer in humans. Besides that, in kretek cigarettes contain various additives that are different as spices that can create a unique taste for each type of cigarette. Some of them are ammonia which can increase the absorption of nicotine alkaloids[11].

\section{Carbon Monoxide (CO) Levels in the Home}

For carbon monoxide levels based on the results of the study showed that there were 12 or as many as $26.7 \%$ of the samples contained CO levels of more than $30,000 \mu \mathrm{g}$ / NM3 and as many as 33 or as many as $73.3 \%$ of room samples with CO levels of less than 30,000 $\mu \mathrm{g} / \mathrm{NM} 3$. The living environment can also be one of the causes for the increase in $\mathrm{COHb}$ levels in the blood, so that someone who lives in an environment I room with high ambient $\mathrm{CO}$ gas can increase a person's $\mathrm{COHb}$ levels in their blood, even though the cause of an increase in $\mathrm{COHb}$ levels in the blood is not the only one. caused by $\mathrm{CO}$ gas that is inhaled through the air, but a condition in a person's disease such as chronic lung disease can also increase $\mathrm{COHb}$ levels in a person's blood. Carbon monoxide (CO) is known to affect the work of the heart (cardiovascular system), central nervous system, fetuses, and all organs of the body that are sensitive to lack of oxygen. The effect of carbon monoxide (CO) on the cardiovascular system is quite significant, although at low levels. One cigarette that is burned contains 3-6\% carbon monoxide and the blood level reaches $5 \%$. In non-smokers, the level is $1 \%$. 
Smokers with carbon monoxide levels of 5\% and above have three times more attacks than nonsmokers. The combination of carbon monoxide with nicotine will make it easier for smokers to suffer from narrowing and closing of the blood vessels and its consequences[12].

\section{Carboxyhemoglobin COHb levels}

The most important biological characteristic of $\mathrm{CO}$ is its ability to bind to hemoglobin, the red blood pigmentel that carries oxygen throughout the body. This property will result in the formation of carboxyhaemoglobin ( $\mathrm{HbCO}$ ) which is 200 times more stable than Oxyhaemoglobin $(\mathrm{HbO} 2)$. The relatively slow breakdown of $\mathrm{HbCO}$ causes inhibition of the work of the pigment cell molecules in their function of carrying oxygen throughout the body. This condition can be serious to fatal, because it can cause poisoning[13].

Of the total 45 samples we studied, it was seen that 9 samples $(20 \%)$ had carboxyhemoglobin levels of more than $10 \%$ and 36 samples (80\%) had less than $10 \%$ carboxyhemoglobin levels. This shows that 9 samples in this study are at risk of experiencing $\mathrm{CO}$ poisoning. Carbon monoxide (CO) gas that enters the circulatory system will replace the position of oxygen in binding to hemoglobin $(\mathrm{Hb})$ in the blood. CO gas eventually easily enters the heart, brain and other vital organs that support human life. This gas is very toxic to the human body, so the consequences can be fatal. The $\mathrm{CO}$ and $\mathrm{Hb}$ bonds in the blood will form carboxy hemoglobin[14].

Another factor that can increase $\mathrm{COHb}$ levels is age. Decreased cardiovascular capacity due to aging and reduced elasticity of lung tissue function, making a person more susceptible to exposure to CO gas [14].

From these studies, it can be seen that the duration of smoking, the number of cigarettes smoked, the types of cigarettes, and the indoor $\mathrm{CO}$ levels are not significantly related to carboxyhemoglobin in active smokers in the Kemaraya Family Environment of Kendari City.

\section{CONCLUSION}

From these studies, it can be seen that the duration of smoking, the number of cigarettes smoked, the types of cigarettes, and the indoor $\mathrm{CO}$ levels are not significantly related to carboxyhemoglobin in active smokers in the Kemaraya Family Environment III of Kendari City

\section{REFERENCES}

1. Aji Amri, L.M.A.S.A "Isolation of Nicotine from Cigarette Butts as an Insecticide," Jurnal of Chemical Technology Unimal, vol. 4, no. 1, pp. 100-120, 2015.

2. Sari, G. Environmental Pollution and Destruction and Countermeasures, Yogyakarta: TP. Pustaka Insan Madani, 2009.

3. Rogaya, Cigarette Smoke As Pollutants In The Room, Jakarta: Departemen Pulmonologi dan Ilmu Kedokteran Respirasi, 2017.

4. Health Ministry of Republic of Indonesia, Basic Health Research, Jakarta, 2013.

5. Sopiyudin, D. Statistics For Medicine And Health, Jakarta: Salemba Medika, 2009.

6. S. Triswanto, Stop Smoking, Jakarta: Progresif Books, 2007.

7. Nadia, L. The Negative Effects of Smoking on Health and Awareness of Urban Communities," in The Negative Effects of Smoking on Health and Awareness of Urban Communities, 2016, pp. 77-104.

8. PMI, The Health Impact of Smoking Smoking Cause Serious Illness And Addiction Are All Cigarettes Or Cigars Harmful And Addictive? Tar, Nicotine, And Carbon Monoxide Levels of Passive Cigarette Smoke, 2018. 
Lestari, S.A., T. Saparina L, \& L. Ali. DOI: 10.36566/ijhsrd/Vol3.Iss1/69

https://ijhsrd.com/index.php/ijhsrd

9. Dinas Kesehatan Republik Indonesia, Indonesian Community Smoking Behavior, 2014, pp. 1-11.

10. Susanna, Dewi B.H.A.H.F. Determination Of Nicotine Levels In Cigarette Smoke, 2003.

11. Bustan, Epidemiology of NonCommunicable Diseases, Jakarta: Rineka Cipta, 2000.

12. Dewanti, R. "Identification of $\mathrm{CO}$ Exposure, Habits, $\mathrm{COHb}$ Blood and Worker's Health Complaints on Basement Waterplace Apartment, Surabaya, Journal of Environmental Health, vol. 10, no. 1, pp. 59-69, 2018.

13. Rogaya, Cigarette Smoke As Pollutants In The Room, Jakarta: Departement of Pulmonology and Respiratory Medicine, 2017.

14. Sadikin, Blood Biochemistry, Jakarta: Widya Medika, 2012. 